\title{
THE EFFECTS OF HISTAMINE ON THE CONTROL OF CORNEAL NEOVASCULAR MOTILITY IN RATS
}

\author{
DANIELA BIANCA DAMIAN ${ }^{1}$, ISABEL GHIȚA ${ }^{1 *}$, RAZVAN DANIEL IONESCU $^{2}$, ION \\ FULGA $^{1}$
}

${ }^{I}$ Departament of Pharmacology and Pharmacotherapy, Faculty of Medicine, "Carol Davila” University of Medicine and Pharmacy, Bucharest, Romania

${ }^{2}$ Ophtalmic Emergency Clinical Hospital, Bucharest, Romania

*corresponding author: isabelghita@yahoo.co.uk

Manuscript received: June 2020

\begin{abstract}
The aim of this study was to evaluate the existence of a possible histaminergic control in the corneal neovessels, in 45-dayold rat pups, on the model of neovascularization performed with ketamine. The experiments were performed on 45-day-old Wistar rats in which, starting with day 15, the experimental model of neovascularization was obtained by means of 5 repeated injections of ketamine at a dose of $150 \mathrm{mg} / \mathrm{kg}$ body weight. Recordings were made for each eye that developed neovascularization by examining 6 eyes for each experiment. Visualization of corneal neovascularization was performed using a Nikon stereomicroscope, model SMZ 1270, connected to a Mshot video camera. The total magnification was 400X. The diameter of the neovessel was measured at a chosen point, the same point/points for each recording made to that eye, over a period of 630 seconds, at different times. The parameters followed were the variations of the vascular calibre, the data obtained being analysed with Microsoft Office Excel. The results showed that there are histaminergic receptors in the corneal neovessels because histamine had a vasodilating effect. It has also been found that there are both H1-type and H2-type histaminergic receptors at this level, as both ranitidine and olopatadine have blocked the vasodilating effect of histamine. As neither ranitidine nor olopatadine had any effects when administered alone, it leads us to conclude that there is no histaminergic tonic control in the corneal neovessels.
\end{abstract}

\section{Rezumat}

Scopul acestui studiu a fost evaluarea existenței unui posibil control histaminergic asupra neovaselor corneene, la puii de şobolan în vârstă de 45 de zile, la modelul de neovascularizaţie realizat cu ketamină. Experimentele au fost realizate pe şobolani rasa Wistar de 45 de zile cărora, începând cu ziua a 15-a, li s-a indus un model experimental de neovascularizație ce a fost obținut prin 5 injectări repetate de ketamină în doză de $150 \mathrm{mg} / \mathrm{kgc}$. Înregistrările au fost făcute pentru fiecare ochi care a dezvoltat neovascularizație prin examinarea a câte 6 ochi pentru fiecare experiment. Vizualizarea neovascularizației corneene a fost realizată utilizând un stereomiscroscop Nikon, conectat la o camera video Mshot, model SMZ 1270. Magnificația totală a fost de 400X. S-a măsurat diametrul neovasului într-un punct ales, același punct/puncte pentru fiecare înregistrare făcută ochiului respectiv, pe o perioadă de 630 secunde, în diferite momente. Parametrul urmărit a fost variația calibrului vascular, datele obținute fiind analizate cu ajutorul Microsoft Office Excel. Rezultatele au arătat că există receptori histaminergici la nivelul neovaselor corneene, deoarece histamina a avut un efect vasodilatator. De asemenea, s-a observat că ambele tipuri de receptori histaminergici H1 și H2 există la acest nivel, deoarece atât ranitidina, cât și olopatadina, au blocat efectul vasodilatator al histaminei. Având în vedere că nici ranitidina și nici olopatadina nu au avut efect când au fost administrate singure, putem concluziona că nu există un control tonic histaminergic asupra neovaselor corneene.

Keywords: histamine, neovessels, cornea, vasodilator

\section{Introduction}

At the ocular level, the vascularization represents a complex structure, with a number of particularities and it is involved in physiological and pathological processes. Similar to other vascular systems in the human body and CNS, the tone of the ocular vessels can be modulated by a number of factors [5], namely the nervous system and the same locally active substances such as histamine, epinephrine and acetylcholine [20]. Aside from these, the adrenergic system has been proven to work synergistically with the cholinergic and histaminergic system in CNS [8]. Histamine is a vasoactive biogenic amine, widespread in nature, discovered in 1910 by Sir Henry Hallett Dale. In humans, it is found in large quantities in the skin, digestive tract and lung tissue. Histamine is formed from the amino acid histidine, through a decarboxylation process, under the action of histidine decarboxylase. Telford and West stated in 1961 that the enzymatic activity in rats varies from tissue to tissue and that in this species there may be several enzymes capable of forming histamine. After synthesis, histamine is rapidly inactivated or stored. Histamine is stored in 
mast cells [15], but also in basophilic leukocytes or platelets (in some species), or in enterocromafinelike cells (ECL) in the stomach [14]. The release of histamine from the deposits can happen both spontaneously, but especially during physical or chemical aggression, in allergic or inflammatory reactions.

Histamine exerts its functions through histaminergic receptors in cell membranes in various tissues. To date, four types of histaminergic receptors have been identified, namely $\mathrm{H} 1, \mathrm{H} 2, \mathrm{H} 3$ and $\mathrm{H} 4$, which are serpentine-type receptors coupled to $G$ proteins. Histamine is involved in the generation of the "triple Lewis reaction" [7] mediated by $\mathrm{H} 1$ receptors, but also in the secretion of hydrochloric acid mediated by $\mathrm{H} 2$ receptors. Histamine also has the role of neurotransmitter in the central nervous system, is involved in haematopoiesis, immunomodulatory processes, etc. Histamine synthesis is increased during healing processes, suggesting that it may play an important role during healing [13].

In humans, in the normal conjunctiva there are around 5000 - 6000 mast cells $/ \mathrm{mm}^{3}$, which contain approximately $4.6 \mathrm{pg}$ of histamine/cell. In type I hypersensitivity reactions, both in the early and late stages, histamine is released from mast cell granules and basophils [12]. Conjunctival hyperaemia and chemosis are caused by the activation of $\mathrm{H} 1$ receptors, located mainly in vascular endothelial cells, epithelial cells and nerve fibres at the level of the ocular surface [11]. At the level of the ocular surface there may also be $\mathrm{H} 2$ receptors [1], which can produce vasodilation $[6,12]$. Leonardi and colleagues demonstrated in 2011 by means of immunohistochemistry techniques that H3 receptors may be present at the conjunctival level under normal conditions or conjunctival inflammation, while $\mathrm{H} 4$ receptors appear in all inflamed tissues [11]. At the ocular level, neovascularization is related to decreased visual acuity, which can lead to blindness in severe cases, affecting the quality of life. Currently, existing treatments include anti-VEGF (vascular endothelial growth factor) injections, laser treatment or phototherapy, topical treatments or corneal transplantation in the case of corneal neovessels $[2,17]$. Ocular neovascularization has been and will remain a challenge in terms of discovering some types of receptors present in the neoformation of vessels that could be medically influenced in order to decrease their progression.

The aim of this study was to assess whether histamine exerts a possible control on corneal neovessels in 45-day-old rat pups.

\section{Materials and Methods}

The experiments were performed on 45-day-old Wistar rats weighing between $47 \mathrm{~g}$ and $75 \mathrm{~g}$, in which the experimental model of neovascularization was obtained by five repeated injections of ketamine at a dose of $150 \mathrm{mg} / \mathrm{kg}$ body weight. We initially aimed to investigate sodium selenite-induced cataract in 15-day-old rat pups, in which the in vivo tracking of lens opacities was no longer possible due to changes in corneal transparency during the study. Under these conditions, the question was whether the trigger for corneal opacity/neovascularization is sodium selenite or ketamine used as a general anaesthetic, so we set out to evaluate changes in corneal transparency. Research has shown that these corneal changes are produced by ketamine and not by sodium selenite, which agrees with the existing data in the literature $[5,6,10,18,19]$. The development of the experimental model of corneal neovascularization was performed in the Department of Pharmacology of the "Carol Davila" University of Medicine and Pharmacy, Bucharest, Romania. Currently, there is no reference model for the induction of corneal neovessels with ketamine. The animals were provided by the Biobase of the "Carol Davila" University of Medicine and Pharmacy, Bucharest. Animals were brought to the working laboratory and kept in standard environmental conditions. The animals had ad libitum access to food and water and were housed in plexiglass cages. The ambient temperature was between 21 and $24^{\circ} \mathrm{C}$, and the relative humidity maintained between $45-60 \%$. The recordings were made for each eye with neovascularization, 5 groups of animals, 6 eyes for each experiment. The experiments were carried out with the approval of the Ethics Commission of the "Carol Davila" University of Medicine and Pharmacy, Bucharest, as well as in accordance with the provisions of the European Directive 86/609/EEC on working with laboratory animals and the Romanian Law in force No. 43/2014 on the protection of animals used for scientific purposes.

The substances used were ketamine, $10 \%$ solution (CP-Ketamine 10\%, CP-Pharma, Germany, veterinary medicine), distilled water (Zentiva SA, Romania), olopatadine, ophthalmic solution $1 \mathrm{mg} / \mathrm{mL}$ (Opatanol $1 \mathrm{mg} / \mathrm{mL}$, eye drops, Alcon, UK), ranitidine, solution for injection, $50 \mathrm{mg} / 2 \mathrm{~mL}$ (Arnetin $50 \mathrm{mg} / 2 \mathrm{~mL}$, Medochemie LTD, Cyprus) and histamine, powder with purity over 99\% (Histamine dihydrochloride, Sigma Aldrich, USA). Ketamine was administered by injection, intra-peritoneally, while distilled water, olopatadine, ranitidine and histamine were administered externally, at the conjunctival level, as solutions. We used equimolar solutions for each batch of experiments: olopatadine, histamine dihydrochloride and ranitidine solution, all with a $3 \mathrm{mM}$ concentrantion.

The rat pups were injected intraperitoneally with ketamine at a dose of $150 \mathrm{mg} / \mathrm{kg}$ body weight (b.w.) on days $15,20,25,30$ and 35 of life to obtain neovascularization. On day 35 of life, respectively at the last administration of ketamine in order to obtain neovascularization, the rats that showed neovascularization were selected (Figure 1). 
FARMACIA, 2021, Vol. 69, 1

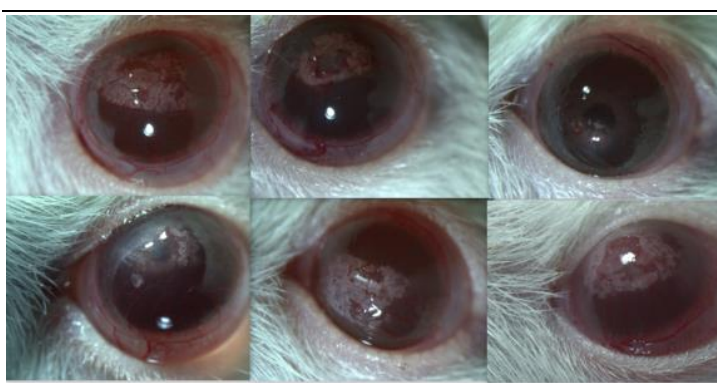

Figure 1.

Examples of images with corneal neovascular changes

Precisely 10 days after the last ketamine injection, each rat was anesthetized with ketamine at a dose of $150 \mathrm{mg} / \mathrm{kg}$ b.w. injected intraperitoneally. The substances to be researched, histamine and its antagonists (ranitidine and olopatadine), were applied at the conjunctival level, without touching the ocular surface, by instillation, according to the working protocol, in the moments T1 (30 seconds) and T6 (330 seconds). The moments of measurement of the vascular diameters were: T0 (0 seconds), T1 (30 seconds), T2 (90 seconds), T3 (150 seconds), T4 (210 seconds), T5 (270 seconds), T6 (330 seconds), T7 (390 seconds), T8 (450 seconds), T9 (510 seconds), T10 (570 seconds) and T11 (630 seconds). Moments T1 and T6, when the substances to be investigated were applied, were not analysed. Five experiments were performed. In the first experiment we tracked the effect of histamine on neoformation vessels by administering distilled water at $\mathrm{T} 1$ and histamine at T6. In the second experiment, olopatadine was administered at time $\mathrm{T} 1$ and histamine at time T6. In the third experiment, ranitidine was administered at time $\mathrm{T} 1$ and histamine at time T6. In the fourth experiment, distilled water was administered at time T1 and olopatadine at time T6, and in the last experiment distilled water was administered at time $\mathrm{T} 1$, and ranitidine at time $\mathrm{T} 6$.

To visualize the corneal neovascularization, a Nikon stereomicroscope was used, model SMZ 1270, connected to a Mshot video camera, model MSX2-C, which was connected to a computer. The video camera was equipped with an intermediate lens attached to the front of the sensor to compensate for the magnification from the stereo-microscope eyepieces. The system was manually calibrated using the "Mshot Imaging Analysis System" software and the Nikon micrometric calibration blade, type B $(1 \mathrm{Div}=0.1 \mathrm{~mm}=100 \mu \mathrm{m})$, J28004 series. The total magnification was 400X.

The anesthetized rats were placed in lateral decubitus in a restraint device to ensure optimal access to the eyeball to be examined, the eyelid slit being kept open by manual traction. The examination was performed for each eye that presented neovascularization, 6 eyes per experiment. The images were recorded at set intervals of 60 seconds for each eye to be examined throughout the recording period. The recordings were made from the same working distance for each eye, in order to have the same magnification factor, and subsequently data processing was performed. For each eye there are 12 images saved as .jpg files and a video recording, in MP4 format, with a total duration of $10 \mathrm{~min}$ and $30 \mathrm{sec}$. The images were processed in the Mshot Imaging Analysis System program.

The diameter of the neovessels was measured at a chosen point, the same point(s) for each recording made to that eye throughout the recording period. For each image of the chosen T0 - T11 moment, 3 diameter measurements were performed at the same points, for which the average was calculated.

The parameters under investigation were variations in the vascular calibre (vasodilation/vasoconstriction), and the measurements were expressed in micrometres. For each moment of each determination the percentage variation of the neovascular diameter relative to the moment T0 was calculated according to the following formula:

$$
\text { Drel }=\left(\frac{D x-D 0}{D 0}\right) \times 100,
$$

where: Drel represents the percentage variation of the neovascular diameter from the moment T0; Dx represents the diameter in $\mu \mathrm{m}$ of the neovessel at the measured moment; D0 represents the diameter in $\mu \mathrm{m}$ from the moment T0. Positive values of Drel are considered to be the expression of a vasodilating effect, while negative values are considered to be the expression of a vasoconstrictor effect. The data obtained were analysed using Microsoft Office Excel. For each group and for each moment of the determinations, the mean and the standard error were calculated, after which the T-Student test was applied, the variant for paired samples (2-tailed, 1 paired), comparing Drel with the value from the $\mathrm{T} 0$ moment. The results were considered statistically significant if $\mathrm{p}<0.05$.

\section{Results and Discussion}

The effect of histamine on neoformation of vessels The results obtained after the administration of histamine at the level of corneal neovessels are presented in Table I and Figure 2.

By administration of distilled water at time $\mathrm{T} 1$ it is observed that there were no statistically significant changes in the neovascular calibre at times T2-T5. By administration of histamine at time $\mathrm{T} 6$ it can be noticed that the average percentage change of neovascular diameter recorded at time $\mathrm{T} 7$ was $21.02 \% \pm 4.63$, $23.39 \% \pm 3$ at time $\mathrm{T} 8,27.93 \% \pm 4.63$ at time $\mathrm{T} 9$, $24.19 \% \pm 4.02$ at time $\mathrm{T} 10$ and $23.94 \% \pm 4.13$ at time T11, all these diameter increases being statistically significant compared to time $\mathrm{T} 0(\mathrm{p}<0.05)$. In conclusion, it has been observed that histamine produces vasodilation in the corneal neoformation vessels, from time $\mathrm{T} 7$ to time T11. 
Table I

Evolution over time of the percentage change in neovascular diameter after administration of distilled water at time $\mathrm{T} 1$, subsequently after administration of $3 \mathrm{mM}$ histamine at time $\mathrm{T} 6$

\begin{tabular}{|l|c|c|c|}
\hline $\begin{array}{c}\text { Image capture time } \\
\text { (seconds) }\end{array}$ & $\begin{array}{c}\text { Average percentage change } \\
\text { in neovascular diameter \% }\end{array}$ & $\begin{array}{c}\text { Standard } \\
\text { error }\end{array}$ & $\begin{array}{c}\text { p-value } \\
\text { (t-test) }\end{array}$ \\
\hline T0 - 0 s (control) & 0 & 0 & 0 \\
\hline T1 - 30 s & Administration of distilled water \\
\hline T2 - 90 s & -1.07 & 2.71 & 0.71 \\
\hline T3 - 150 s & 0.28 & 3.27 & 0.93 \\
\hline T4 - 210 s & 0.73 & 2.66 & 0.79 \\
\hline T5 - 270 s & 1.78 & 4.14 & 0.68 \\
\hline T6 - 330 s & Histamine 3 mM administration \\
\hline T7 - 390 s & 21.02 & 4.63 & 0.006 \\
\hline T8 - 450 s & 23.39 & 3.00 & 0.0005 \\
\hline T9 - 510 s & 27.93 & 4.63 & 0.001 \\
\hline T10 - 570 s & 24.19 & 4.02 & 0.001 \\
\hline T11 - 630 s & 23.94 & 4.13 & 0.002 \\
\hline
\end{tabular}

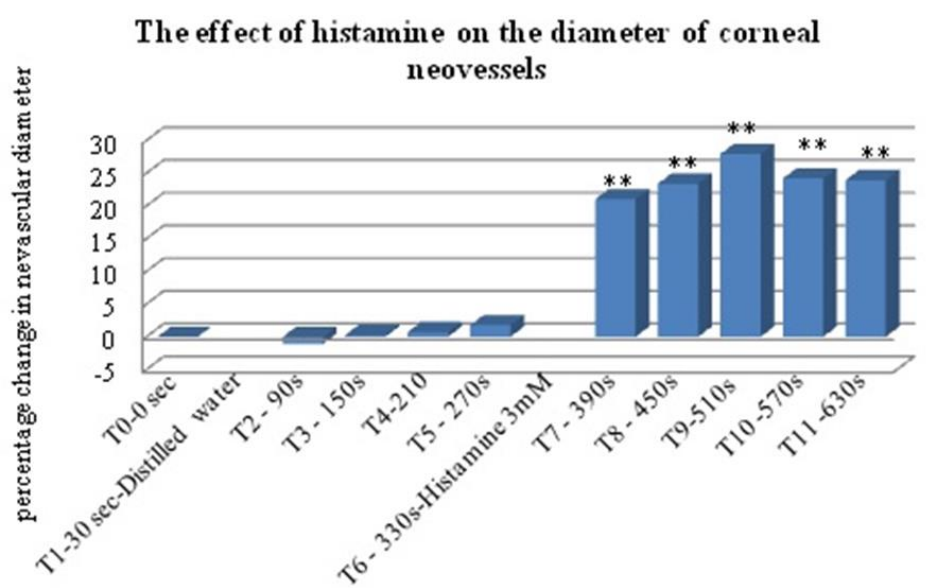

Figure 2.

The evolution over time of the percentage variation of the neovascular diameter after the administration of distilled water at time $\mathrm{T} 1$, subsequently after the administration of $3 \mathrm{mM}$ histamine at time $\mathrm{T} 6$

The moments at which the determinations were performed are represented horizontally and percentage variation of the neovascular diameter vertically. There were statistically significant changes for moments T7, T8, T9, T10 and T11 (** $\mathrm{p}<0.05)$.

The effect of histamine after olopatadine on neoformation vessels

In the second experiment, the effect of histamine was followed after the previous administration of olopatadine, an $\mathrm{H} 1$ receptor blocker. These results are presented in
Table II and Figure 3. Administration of olopatadine at time $\mathrm{T} 1 \mathrm{did}$ not produce statistically significant changes in neovascular diameter. Nor did histamine administration after olopatadine cause statistically significant changes.

Table II

Evolution over time of the percentage change in neovascular diameter after administration of $3 \mathrm{mM}$ olopatadine at time $\mathrm{T} 1$, respectively after administration of $3 \mathrm{mM}$ histamine at time $\mathrm{T} 6$

\begin{tabular}{|l|c|c|c|}
\hline $\begin{array}{c}\text { Image capture time } \\
\text { (seconds) }\end{array}$ & $\begin{array}{c}\text { Average percentage change } \\
\text { in neovascular diameter \% }\end{array}$ & $\begin{array}{c}\text { Standard } \\
\text { error }\end{array}$ & $\begin{array}{c}\text { p-value } \\
\text { (t-test) }\end{array}$ \\
\hline T0 - 0 s (control) & \multicolumn{2}{|c|}{0} & 0 \\
\hline T1 - 30 s & Olopatadine 3 mM administration \\
\hline T2 - 90 s & 1.22 & 5.27 & 0.82 \\
\hline T3 - 150 s & -3.78 & 3.63 & 0.34 \\
\hline T4 - 210 s & -6.21 & 5.10 & 0.27 \\
\hline T5 - 270 s & -3.90 & 5.38 & 0.50 \\
\hline T6 - 330 s & Histamine 3 mM administration \\
\hline T7 - 390 s & -3.19 & 9.23 & 0.74 \\
\hline T8 - 450 s & -2.22 & 8.39 & 0.80 \\
\hline T9 - 510 s & 3.91 & 7.60 & 0.62 \\
\hline T10 - 570 s & 5.94 & 7.38 & 0.45 \\
\hline T11 - 630 s & 6.47 & 7.90 & 0.45 \\
\hline
\end{tabular}




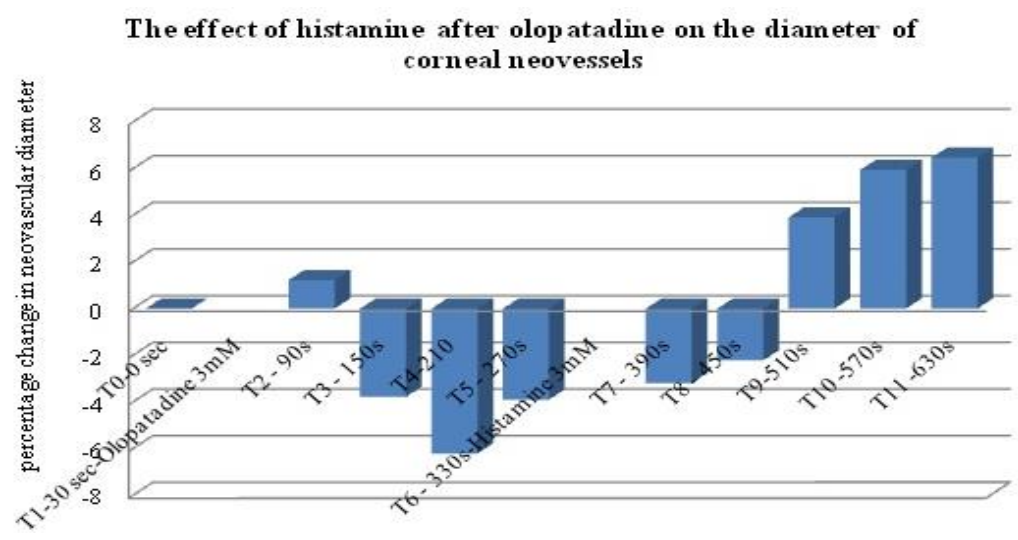

Figure 3.

Evolution over time of the percentage change in neovascular diameter after administration of $3 \mathrm{mM}$ olopatadine at time $\mathrm{T} 1$, respectively after administration of $3 \mathrm{mM}$ histamine at time $\mathrm{T} 6$

The moments at which the determinations were performed are represented horizontally, and the percentage variation of the neovascular diameter vertically. There were no statistically significant changes.

The effect of histamine after ranitidine on neoformation of vessels

In the third experiment, we looked at the effect of histamine on neovascular diameter after prior ranitidine administration. Ranitidine administration at time $\mathrm{T} 1$ did not produce statistically significant changes, and histamine administration after ranitidine did not lead to statistically significant changes either. The results are shown in Table III and Figure 4.

Table III

Evolution over time of the percentage change in neovascular diameter after administration of ranitidine $3 \mathrm{mM}$ at time T1, respectively after administration of histamine $3 \mathrm{mM}$ at time T6

\begin{tabular}{|l|c|c|c|}
\hline $\begin{array}{c}\text { Image capture time } \\
\text { (seconds) }\end{array}$ & $\begin{array}{c}\text { Average percentage change } \\
\text { in neovascular diameter \% }\end{array}$ & $\begin{array}{c}\text { Standard } \\
\text { error }\end{array}$ & $\begin{array}{c}\text { p-value } \\
\text { (t-test) }\end{array}$ \\
\hline T0 - 0 s (control) & \multicolumn{2}{|c|}{0} & 0 \\
\hline T1 - 30 s & Ranitidine 3 mM administration \\
\hline T2 - 90 s & 0.89 & 3.07 & 0.78 \\
\hline T3 - 150 s & -3.08 & 3.38 & 0.40 \\
\hline T4 - 210 s & -5.76 & 3.47 & 0.15 \\
\hline T5 - 270 s & -5.34 & 3.35 & 0.17 \\
\hline T6 - 330 s & Histamine 3 mM administration \\
\hline T7 - 390 s & 3.38 & 5.10 & 0.53 \\
\hline T8 - 450 s & 5.17 & 5.02 & 0.35 \\
\hline T9 - 510 s & 9.24 & 5.43 & 0.14 \\
\hline T10 - 570 s & 13.39 & 8.89 & 0.15 \\
\hline T11 - 630 s & 10.97 & 0.24 \\
\hline
\end{tabular}

The effect of histamine after ranitidine on the diameter of corneal neovessels

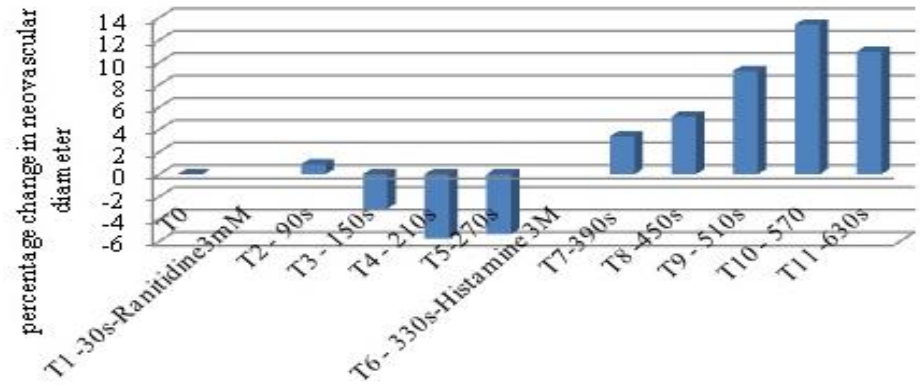

Figure 4.

The evolution over time of the percentage change of the neovascular diameter after the administration of ranitidine $3 \mathrm{mM}$ at time $\mathrm{T} 1$, respectively after the administration of histamine $3 \mathrm{mM}$ at time T6

The moments at which the determinations were performed are represented horizontally, and the percentage variation of the neovascular diameter vertically. There were no statistically significant changes. 
FARMACIA, 2021, Vol. 69, 1

The effect of olopatadine on neoformation of vessels In the fourth experiment, we aimed to influence the neovascular diameter by administering $3 \mathrm{mM}$ olopatadine that blocks $\mathrm{H} 1$ receptors. Olopatadine did not produce statistically significant changes in neovascular diameter. The results obtained from this experiment are presented in Table IV and Figure 5.

Table IV

Evolution over time of the percentage change in neovascular diameter after administration of distilled water at time T1, then after administration of $3 \mathrm{mM}$ olopatadine at time T6

\begin{tabular}{|l|c|c|c|}
\hline $\begin{array}{c}\text { Image capture time } \\
\text { (seconds) }\end{array}$ & $\begin{array}{c}\text { Average percentage change } \\
\text { in neovascular diameter \% }\end{array}$ & $\begin{array}{c}\text { Standard } \\
\text { error }\end{array}$ & $\begin{array}{c}\text { p-value } \\
\text { (t-test) }\end{array}$ \\
\hline T0 - 0 s (control) & 0 & 0 & 0 \\
\hline T1 - 30 s & \multicolumn{2}{|c|}{ Administration of distilled water } \\
\hline T2 - 90 s & -1.09 & 3.53 & 0.76 \\
\hline T3 - 150 s & -1.89 & 3.58 & 0.61 \\
\hline T4 - 210 s & -1.83 & 3.58 & 0.63 \\
\hline T5 - 270 s & 0.36 & 2.79 & 0.90 \\
\hline T6 - 330 s & Olopatadine 3 mM administration \\
\hline T7 - 390 s & -1.05 & 5.92 & 0.86 \\
\hline T8 - 450 s & -7.51 & 7.08 & 0.33 \\
\hline T9 - 510 s & -10.89 & 5.53 & 0.10 \\
\hline T10 - 570 s & -12.92 & 6.33 & 0.09 \\
\hline T11 - 630 s & -12.21 & 6.07 & 0.10 \\
\hline
\end{tabular}

The effect of olop atadine on the diameter of corneal neovessels

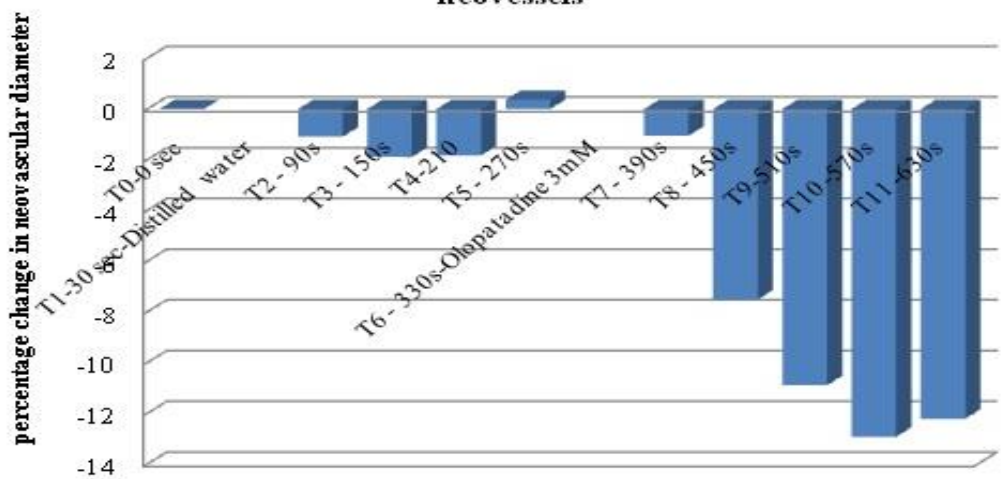

Figure 5.

Evolution over time of the percentage change in neovascular diameter after administration of distilled water at time T1, then after administration of $3 \mathrm{mM}$ olopatadine at time T6

The moments at which the determinations were performed are represented horizontally, and the percentage variation of the neovascular diameter vertically. There were no statistically significant changes.

Table V

Evolution over time of the percentage change in neovascular diameter after administration of distilled water at time $\mathrm{T} 1$, respectively after administration of ranitidine $3 \mathrm{mM}$ at time T6

\begin{tabular}{|l|c|c|c|}
\hline $\begin{array}{c}\text { Image capture time } \\
\text { (seconds) }\end{array}$ & $\begin{array}{c}\text { Average percentage change } \\
\text { in neovascular diameter \% }\end{array}$ & $\begin{array}{c}\text { Standard } \\
\text { error }\end{array}$ & $\begin{array}{c}\text { p-value } \\
\text { (t-test) }\end{array}$ \\
\hline T0 - 0 s (control) & 0 & 0 & 0 \\
\hline T1 - 30 s & Administration of distilled water \\
\hline T2 $-\mathbf{9 0}$ s & 6.7 & 3.40 & 0.10 \\
\hline T3 - 150 s & 3.02 & 1.51 & 0.10 \\
\hline T4 - 210 s & 2.45 & 1.82 & 0.23 \\
\hline T5 - 270 s & 0.07 & 1.75 & 0.96 \\
\hline T6 - 330 s & Ranitidine 3 mM administration \\
\hline T7 - 390 s & 2.99 & 3.53 & 0.43 \\
\hline T8 - 450 s & -1.45 & 1.98 & 0.49 \\
\hline T9 - 510 s & -3.31 & 2.23 & 0.19 \\
\hline T10 - 570 s & -4.10 & 2.79 & 0.20 \\
\hline T11 - 630 s & -9.00 & 3.66 & 0.06 \\
\hline
\end{tabular}


The effect of ranitidine on neoformation of vessels In the last experiment we tracked the evolution over time of the percentage variation of the neovascular diameter after the administration of distilled water at time $\mathrm{T} 1$ and subsequently after the administration of ranitidine at time T6. As seen in Table $\mathrm{V}$ and Figure 6, we found that ranitidine administration did not produce statistically significant changes in the neovascular calibre.

\section{The effect of ranitidine on the diameter of corneal neovessels}

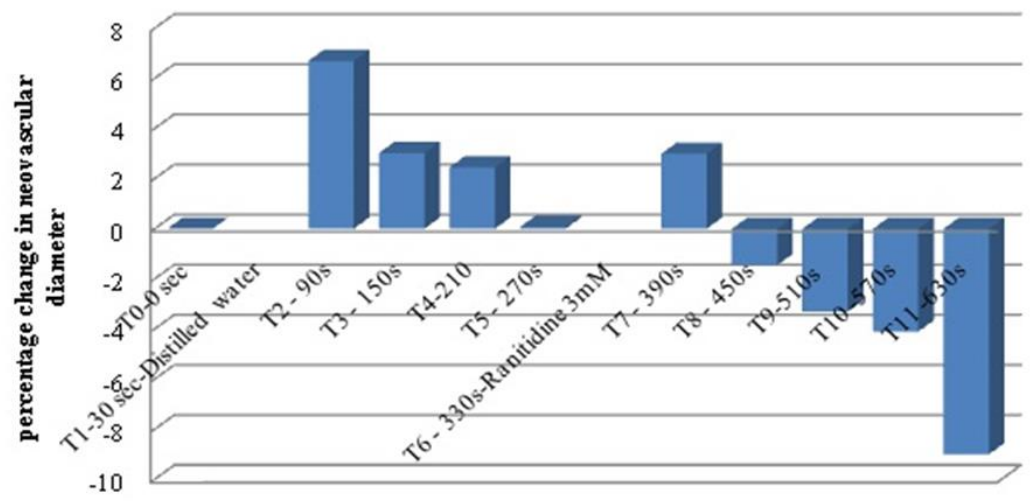

Figure 6.

Evolution over time of the percentage change in neovascular diameter after administration of distilled water at time $\mathrm{T} 1$, respectively after administration of ranitidine $3 \mathrm{mM}$ at time $\mathrm{T} 6$

The moments at which the determinations were performed are represented horizontally, the percentage variation of the neovascular diameter vertically. There were no statistically significant changes.

Histamine produces vasodilation through $\mathrm{H} 1$ and $\mathrm{H} 2$ receptors [4, 9]. $\mathrm{H} 2$ receptors are involved in the relaxation of vascular smooth muscle [3]. Stimulation of $\mathrm{H} 2$ receptors in large vessels generally causes vasodilation, while stimulation of $\mathrm{H} 1$ receptors leads to vasoconstriction. In small vessels, a complete blockade of the vasodilating effect of histamine can be achieved by the combined administration of $\mathrm{H} 1$ and $\mathrm{H} 2$ receptor antagonists. At the conjunctival level, stimulated vasodilation can be prevented by prior administration of an $\mathrm{H} 2$ receptor antagonist [1]. In our study, the administration of histamine in conjunctival instillations produced vasodilation in the corneal neoformation vessels, which demonstrates that there are histaminergic receptors at this level. Olopatadine is a selective histamine $\mathrm{H} 1$ receptor antagonist [16], which exhibits antihistamine as well as mast cell stabilization and anti-inflammatory activity [9]. The administration of histamine after olopatadine, a blocker of $\mathrm{H} 1$ receptors, did not produce vasodilation, demonstrating that histamine-type $\mathrm{H} 1$ receptors are involved in the production of the vasodilating effect of histamine. The administration of histamine after the previous administration of ranitidine, a blocker of $\mathrm{H} 2$ receptors, did not produce vasodilation either, which demonstrates that histaminergic $\mathrm{H} 2$-type receptors are also involved in the production of the vasodilating effect of histamine. Considering these results we can say that in the corneal neoformation vessels there are both H1-type and H2- type histaminergic receptors, by which histamine produces vasodilation at this level.
Neither the administration of olopatadine alone nor the administration of ranitidine alone caused changes in the diameter of the corneal neoformation vessels, which shows that there is no tonic histaminergic control in these vessels, but probably a phase histaminergic control.

\section{Conclusions}

Histamine administered in conjunctival instillations may cause vasodilation in the corneal neovessels with the help of the $\mathrm{H} 1$ - and $\mathrm{H} 2$ - receptors. $\mathrm{H} 1$ and $\mathrm{H} 2$ type histaminergic receptors are present in the corneal neovessels. In our experimental conditions we can say that at the level of the corneal neovessels there is no histaminergic tonic control.

\section{Conflict of interest}

The authors declare no conflict of interest.

\section{References}

1. Abelson MB, Udell IJ, H2-Receptors in the human ocular surface. Arch Ophthalmol., 1981; 99(2): 302304.

2. Belghmaidi S, Hajji I, Ennassiri W, Benhaddou R, Baha Ali T, Moutaouakil A, La prise en charge des néovaisseaux cornéens avant greffe de cornée: à propos de 112 cas. J Fr Ophtalmol., 2016; 39(6): 515-520, (available in French).

3. Bielroy L, Allergic and immunologic disorders of the eye. Part II: Ocular allergy. J Allergy Clin Immunol., 2000; 106(6): 1019-1032. 
4. Bungardt E, Buschauer A, Moser U, Schunack W, Lambrecht G, Mutschler E, Histamine H1 receptors mediate vasodilation in guinea-pig ileum resistance vessels: characterization with computer-assisted videomicroscopy and new selective agonists. Eur $J$ Pharmacol., 1992; 221(1): 91-98.

5. Coman OA, Țăranu B, Ghiţă I, Fulga I, Particularities of vascular reactivity of the conjunctiva and iris in rats. Romanian J Morphol Embryol., 2008; 49(1): 53-56.

6. Coman OA, Rotar C, Stoleru S, Ghiţă, Păunescu H, Fulga I, Influencing vascular reactivity in vivo by histaminergic agonists and antagonists. Romanian $J$ Morphol Embryol., 2007; 48(4): 403-406.

7. Dachman WD, Bedarida G, Blaschke TF, Hoffman $\mathrm{BB}$, Histamine-induced venodilation in human beings involves both $\mathrm{H} 1$ and $\mathrm{H} 2$ receptor subtypes. J Allergy Clin Immunol., 1994; 93(3): 606-614.

8. Handra C, Coman OA, Coman L, Enache T, Stoleru S, Sorescu AM, Ghiță I, Fulga I, The connection between different neurotransmitters involved in cognitive processes. Farmacia, 2019; 67(2): 193-201.

9. Kaliner MA, Oppenheimer J, Farrar JR, Comprehensive review of olopatadine: the molecule and its clinical entities. Allergy Asthma Proc., 2010; 31: 112-119.

10. Koehn D, Meyer KJ, Syed NA, Anderson MG, Ketamine/Xylazine-Induced Corneal Damage in Mice. PLoS One, 2015; 10(7): e0132804: 1-12.

11. Leonardi A, Di Stefano A, Vicari C, Motterle L, Brun P, Histamine $\mathrm{H} 4$ receptors in normal conjunctiva and in vernal keratoconjunctivitis. Allergy, 2011; 66: 13601366.

12. Montan PG, van Hage-Hamsten M, Zetterström O, Sustained eosinophil cationic protein release into tears after a single high-dose conjunctival allergen challenge. Clin Exp Allergy, 1996; 26(10): 1125-1130.
13. Numata $Y$, Terui T, Okuyama R, Hirasawa N, Sugiura Y, Miyoshi I, Watanabe T, Kuramasu A, Tagami H, Ohtsu $\mathrm{H}$, The accelerating effect of histamine on the cutaneous wound-healing process through the action of basic fibroblast growth factor. J Invest Dermatol., 2006; 126(6): 1403-1409.

14. Parsons ME, Ganellin CR, Histamine and its receptors. Br J Pharmacol., 2006; 147(Suppl 1): S127-135.

15. Riley JF, West GB, The presence of histamine in tissue mast cells. J Physiol., 1953; 120(4): 528-537.

16. Sharif NA, Xu SX, Yanni JM, Olopatadine (AL4943A): ligand binding and functional studies on a novel, long acting $\mathrm{H} 1$-selective histamine antagonist and anti-allergic agent for use in allergic conjunctivitis. J Ocul Pharmacol Ther., 1996; 12(4): 401-407.

17. Stanca HT, Stanca S, Tabacaru B, Boruga M, Balta F, Bevacizumab in Wet AMD Treatment: A Tribute to the Thirteen Years of Experience From the Beginning of the anti-VEGF Era in Romania. Exp Ther Med., 2019; 18(6): 4993-5000.

18. Tita B, Leone MG, Casini ML, Corubolo C, Bordi F, Guidolin D, Fumagalli E, Romanelli L, Mattioli F, Fehér J, Saso L, Corneal toxicity of xylazine and clonidine, in combination with ketamine, in the rat. Ophthalmic Res., 2001; 33(6): 345-352.

19. Turner PV, Albassam MA, Susceptibility of rats to corneal lesions after injectable anesthesia. Comp Med., 2005; 55(2): 175-182.

20. Zugravu A, Ghiță ICV, Paunescu H, Coman L, Coman OA, Fulga I, A review on the physiological and pharmacological influence of vascular tone in choroidal and conjunctival eye territories. Farmacia, 2016; 64(5): 656-662. 